\title{
THE HISTORY AND PRACTICE OF LYING IN PUBLIC LIFE
}

\author{
MICHAEL A. PETERS \\ mpeters@waikato.ac.nz \\ University of Waikato; \\ University of Illinois at Urbana-Champaign
}

\begin{abstract}
This paper provides an introduction to the history and practice of lying in public life. The paper argues that such an approach is required to balance the emphasis on truth and truth-telling. Truth and lies, truth-telling and the practice of lying are concepts of binary opposition that help define one another. The paper reviews Foucault's work on truth-telling before analysing the "culture of lying" and its relation to public life by focusing on Arendt's work.
\end{abstract}

Keywords: lying; Foucault; truth-telling; culture of lying; Arendt

To lie is a horrible filthy vice; and which an ancient writer setteth forth very shamefully, when he saith that whosoever lieth witnesseth that he contemneth God and therewithall feareth men. It is impossible more richly to represent the horrour, the vilenesse and the disorder of it: for, what can be imagined so vile and base as to be a coward towards men and a boaster towards God?

--Montaigne, The Second Booke, XVIII, "Of Giving the Lie", at http://ww.w.mises.ch/library/Montaigne_Essays_Florio_Translation.pdf

The deliberate falsehood and the outright lie, used as legitimate means to achieve political ends have been with us since the beginning of recorded history. Truthfulness has never been counted among the political virtues, and lies have always been regarded as justifiable tools in political dealings.

--Hannah Arendt (1971) "Lying in Politics: Reflections on The Pentagon Papers", http://www.nybooks.com/articles/archives/1971/nov/18/lying-in-politicsreflections-on-the-pentagon-pape/

\section{Introduction: Lying and Public Life}

Jeff Malpass (2008) begins his reflection on "Truth, Lies, and Deceit: On Ethics in Contemporary Public Life" by documenting the way truth and deceit in public life has become a major issue in the West. He rightly mentions the huge concern over the deceit and deception by leading politicians involved in the invasion of the Iraq war and notes that the public 
focus of lying and deceit has not been restricted to politics. CEOs of major companies and bank managers (particularly since the Global Financial Crisis) have been involved in systematic fraud, insider trading and deliberate manipulations of the Libor exchange rate. Not only have these corporate players not abided by regulatory obligations and responsibilities but also after being charged they have actively lied, falsified and deceived their clients and the public at large with the result that people have lost their trust in the leading political and business institutions. Untruthfulness, deceit and lying are not restricted to these twin spheres as recent cover-ups in relation to institutional child abuse in the church, in schools, and other related institutions reveal. ${ }^{1}$ Malpass takes the public uproar and controversy as evidence that we still care about truth and truthfulness, and yet he canvases the view that our commitment to truth (Nyberg, 1993; Bailey, 1991), given the extent on deceit and lying in public and personal life, itself might based upon a lie. He goes on to maintain the central significance of truth and truthtelling to questions of self and society:

The question concerning the role and significance of truth and truth-telling lies at the heart of our understanding of ourselveshow we think about truth makes a huge difference to the sort of life we understand ourselves as living, the sort of society we take ourselves to be part of, the sort of relationship we have to the world (p. 2).

Malpass clearly holds that truth, and the commitment to truth, is at the very heart of both ethical practice and the practice of democracy. ${ }^{2}$

In a conference on "Law and Lies" held by the University of Alabama School of Law the question of deception and lying is raised concerning their ubiquity in public life:

From the noble lie of Plato's Republic to the controversy about former President Clinton's "lying" in the Monica Lewinsky case, from the use of secrecy in today's war against terrorism to the endless spinning of political campaigns, from President John Kennedy's behavior during the Cuban missile crisis to cover ups concerning pedophile priests in the Catholic church, from Freud's efforts to decode the secrets beneath civilized life to contemporary exposés of the private lives of politicians, lying and deception seem ubiquitous in our public life. ${ }^{3}$

In a prominent example, the conviction of Lord Archer, one-time chairman of the Conservative party, in the United Kingdom and the many media biographies that quickly followed his downfall, bought home a host of 
questions about the question of lying, not just in public life but also, more generally, in our private lives. With Lord Archer's successful prosecution, listening to the report of his trial, it seems that among his peers conservative politicians, leaders of the party, friends and even his wife lying was considered to be much more heinous than anything to do with his sexual immorality. Indeed, even his wife seemed to tolerate his many affairs outside marriage. As she publicly acknowledged in a TV interview, sexual infidelity was only moderately important to her. Far more important to her, and Archer agreed, was loyalty. Archer's one-night stands with prostitutes were also, it seems, easily forgiven. Sexual 'indiscretions' are tolerated in both public and private morality but lying is not. Is this because our sexual mores and morality have changed whereas the morality of lying has remained more or less the same? Does this speak to the stability of some ethical practices and the relative changeability of others?

Archer's crime officially was perjury, a concept in jurisprudence that refers to the intentional act of swearing a false oath or falsifying an affirmation to tell the truth. Perjury is a statutory offence in England under the Perjury Act of 1911 that states:

If any person lawfully sworn as a witness or as an interpreter in a judicial proceeding wilfully makes a statement material in that proceeding, which he knows to be false or does not believe to be true, he shall be guilty of perjury, and shall, on conviction thereof on indictment, be liable to penal servitude for a term not exceeding seven years, or to imprisonment . . . for a term not exceeding two years, or to a fine or to both such penal servitude or imprisonment and fine.

(http://www.legislation.gov.uk/ukpga/Geo5/1-2/6)

Perjury is the act of a person's deliberately making false or misleading statements while under oath, sometimes termed "false swearing" or "false oath" or in archaic language "forswearing".

Archer was convicted of three charges of perverting the course of justice and one of perjury (committed at the 1987 trial) that centered on allegations he had sex with a prostitute. He was cleared of one charge of perverting the course of justice. Archer also was accused of lying and creating false diaries to win $£ 500,000$ pounds in libel damages from the Daily Star newspaper in 1987. He took the tabloid to court and won after it alleged that he paid prostitute Monica Coghlan for sex in September 1986. This is how the BBC News reported the charges facing Archer:

Lord Archer faced dishonesty charges arising from his successful 1987 libel action, in which he won $£ 500,000$ damages from the 
Daily Star over allegations that he slept with a prostitute. He was accused of asking his former friend Mr Francis, 67, to provide him with a false alibi for a night relating to the libel case and of producing fake diary entries to back up his story. Lord Archer was found guilty of two charges of perjury and two of perverting the course of justice. The first charge was that he perverted the course of justice by asking Ted Francis to give him a false alibi. The second guilty verdict was on a charge that he perverted the course of justice by using a fake diary in the libel trial. He was found to have perjured himself in an affidavit to the High Court for the libel action. He was also found to have perjured himself on oath during the libel trial. He was cleared of a final count of perverting the course of justice in relation to a diary used in the libel case, in which he was awarded $£ 500,000$ after the Daily Star claimed he slept with a prostitute.

(http://news.bbc.co.uk/hi/english/uk/newsid_1424000/1424501.st

$\mathrm{m})$

On reflection one might argue that truth and the absence of lies is at the very basis of jurisprudence as it is in public life. Or perhaps we might say that the methodology for determining the facts of the case and the systematic elimination of lies or lying is close to the heart or spirit of the enterprise. Indeed, one of the objects of the law of evidence is to ensure that witnesses tell the truth and in the past when religious faith was stronger the oath, swearing on the Bible, was deemed to be an effective and appropriate way of ensuring that witnesses told the truth.

Certainly, the religious view in the Christian tradition has taken a very dim view of lying and lies. From the Old Testament, and from Augustine through to Montaigne, lying has been viewed as a sin that admits no reservations. The Old Testament references both concern the issue of false witness, for example, "you shall not bear false witness against your neighbour" (Exodus, 20:16) and how lying is wicked and against the Lord in the following proverbs: "a worthless person, a wicked man,...one with a false mouth", (Proverbs, 6:12); "lying lips are an abomination to the Lord" (Proverbs, 12:22). In the New Testament similar sentiments are expressed through the use of the Greek words for "false" or "lie" (pseudes, pseudomai, pseudos, pseustes) and Greek words for "deceitful" or "false" (dolios, dolioo, dolos, doloo). The Greek word for truth is aletheia, meaning "not hidden." To lie, then, is to hide the truth.

In De Mendacio Augustine takes a hard line on lying; all lies no matter what form are wrong. ${ }^{4}$ That lies are sinful, not surprising, is also the view of the Catholic Church. In Retractions, Augustine suggests that his discussion is "useful for the mind", "profitable for morals" and, most importantly, its significance lies in "inculcating the love of speaking the truth" (ibid.). It is 
this broad theological position that is echoed by Montaigne and both seems to indicate that lying is in some sense a deformation of meaning and language and harmful to society. Sissela Bok (1999: 31) as one of the first modern commentators to revive academic interest in lying adopts a similar view that lying is detrimental to society because it erodes trust as the very foundation of relations among human beings that sustains our institutions. It is argued that truth and truthfulness is a precondition for society.

General introductions to ethics generally emphasize that lying is morally wrong because it breaches trust and erodes trust as a habitual way of being exemplifying the very ethos of society. Thus, for instance, James Rachels (2011) writing about subjectivism in ethics first discusses the basic idea of ethical subjectivism and the evolution of the theory from simple subjectivism to emotivism in order to introduce "moral facts". Rachels then discusses "proofs" in ethics in terms of the process of giving reasons and explaining why reasons matter by offering the following example: once we know that Jones is a bad man because he is a habitual liar, then we can go on to explain why lying is bad. In other words, we can support our judgments with good reasons.

Lying is bad, first, because it harms people. If I give you false information, and you rely on it, things may go wrong for you in all sorts of ways. Second, lying is bad because it is a violation of trust. Trusting another person means leaving oneself vulnerable and unprotected. When I trust you, I simply believe what you say, without taking precautions; and when you lie, you take advantage of my trust. That is why being given the lie is such an intimate and personal offense. And finally, the rule requiring truthfulness is necessary for society to exist - if we could not assume that other people will speak truthfully, communication would be impossible, and if communication was impossible, society would be impossible (pp. 42-43). ${ }^{5}$

This rationalist approach echoes Kurt Baier's (1958) The Moral Point of View that constructs a justification for morality anchored in rationality and reason-giving practices grounded in practical reason that "saves" the enterprise from forms of subjectivism and egoism. The approach does not recognise, however, the geneaological approach to truth-telling or to lying.

\section{Foucault on Truth-telling}

On truth telling as a practice I have been greatly influenced by Foucault's genealogical approach (Peters, 2001). Foucault himself was strongly influenced by his readings of both Friedrich Nietzsche and Martin Heidegger 
and indebted to them for ideas that led him to emphasize the close conceptual relations between the notions of truth, power and subjectivity in his genealogical investigations. Nietzsche's work, in particular, provided Foucault with novel ways to re-theorize and conceive anew the operation of power and desire in the constitution and self-overcoming of human subjects. It enabled him to analyze the modes by which human beings become subjects without according either power or desire conceptual priority over the other, as had been the case in the discourses of Marxism (with its accent on power) and of Freudianism (with its accent on desire).

From Nietzsche's On The Genealogy of Morals (1967), Foucault also intellectually inherited the concept and method of genealogy, a form of historical analysis that inquires into the formation and structure of value accorded Man, Reason, and Truth through a variety of techniques, including both etymological and linguistic inquiry alongside the investigation of the history of concepts. ${ }^{6}$ For Foucault, as for Nietzsche, genealogy replaces ontology. Foucault's investigations into the modes by which human beings are made into subjects are, above all, historical investigations of constellations of practices. For Foucault, as for Nietzsche, there are no essences of human beings and, therefore, also no possibility for universalist theories concerning the nature of human beings. Given that there is no human nature, fixed once and for all -- no essential or universalizable nature -- there is no question of a science of human nature (à la Hobbs or Hume) or the possibility of building or deriving theories of morality, politics, or law on the basis of this alleged nature. All questions of ontology, in the hands of Nietzsche and Foucault, become radically historicized. There is no sovereign individual or transcendental subject, but only human beings that have been historically constituted as subjects in different ways at different times through constellations of practices.

Foucault did not deny either the classical ideal of truth as correspondence to an independently existing world or the contemporary correspondence theory of truth. The early Nietzsche, by contrast, cast doubt precisely on this ideal. For the early Nietzsche truth is a convenient fiction, merely a belief about the possession of truth.

In "On Truth and Lies in an Extra-Moral Sense" Nietzsche writes that "truth" is:

A mobile army of metaphors, metonyms, and anthropomorphisms - in short, a sum of human relations which have been enhanced, transposed, and embellished poetically and rhetorically, and which after long use seem firm, canonical, and obligatory to a people: truths are illusions about which one has forgotten that this is what they are; metaphors which are worn out and without sensuous 
power; coins which have lost their pictures and now matter only as metal, no longer as coins. ${ }^{7}$

This deceptively simple position is based on the understanding that concepts are human inventions and as metaphors they do not correspond to reality. After inventing them we forget that they are only metaphors and treat them as "true" believing that they correspond and picture reality (see Glenn, 2004). There is no match between language and the thing-in-itself. And yet "truth" while based on illusions is still useful for practical purposes. It is also essentially a part of aesthetics and the imagination that creates a mythical truth through a web of concepts to describe the world through art. While Nietzsche's view might strike the reader as idiosyncratic David Simpson (2007) makes the case that there are striking parallels between Nietzsche and Plato on truth and truthfulness and as a consequence they share similar views on the nature of philosophy and its possibilities.

Foucault's innovation was to historicize "truth", first, materially in discourse as "regimes of truth" and, second, in practices as "games of truth". He gave six lectures entitled "Discourse and Truth: The Problematization of Parrhesia", at Berkeley during the months of October-November in $1983 .{ }^{8}$ In these lectures, Foucault outlines the meanings and the evolution of the classical Greek word "parrhesia" and its cognates, as they enter into and exemplify the changing practices of truth-telling in Greek society. In particular, Foucault investigates "the use of parrhesia in specific types of human relationships" and "the procedures and techniques employed in such relationships" (34/66).

Foucault claims that the word parrhesia occurs for the first time in Euripides (c.484-407 BC) and then is used in the Greek world of letters from the end of the Fifth Century BC. The word is normally translated into English as "free speech" and parrhesiastes, the person who uses parrhesia, is the one who speaks the truth. Indeed, the meaning of the word as it evolves in Greek and Roman culture, develops five major characteristics. First, it is associated with frankness: parrhesia refers to a special type of relationship between the speaker and what he says. ${ }^{9}$ Unlike rhetoric, which provides the speaker with technical devices to help him persuade an audience, covering up his own beliefs, in parrhesia, the speaker makes it manifestly clear what he believes. Second, parrhesia is linked with truth. In the Greek, parrhesia is a speech activity where there is an exact coincidence between belief and truth. Foucault (1999: 3) claims: "The "parrhesiastic game' presupposes that the parrhesiastes is someone who has the moral qualities which are required, first, to know the truth, and secondly, to convey such truth to others."

Foucault (1999: 5) provides a summary of his discussion of parrhesia: 
Parrhesia is a kind of verbal activity where the speaker has a specific relation to truth through frankness, a certain relationship to his own life through danger, a certain relation to himself or other people through criticism..., and a specific relation to moral law through freedom and duty. More precisely, parrhesia is a verbal activity in which a speaker expresses his personal relationship to truth, and risks his life because he recognizes truthtelling as a duty to improve or help other people (as well as himself). In parrhesia, the speaker uses his freedom and chooses frankness instead of persuasion, truth instead of falsehood or silence, the risk of death instead of life and security, criticism instead of flattery, and moral duty instead of self-interest and moral apathy.

This new kind of philosophical parrhesia that arises in Greco-Roman culture, Foucault characterizes, first, as "a practice which shaped the specific relations that individuals have to themselves" (40/66). Much of the philosophy that emerged with Socrates and Plato, and shaped the philosophical tradition that is still ours today and which defines the roots of our moral subjectivity involved the playing of certain games of truth.

\section{The Culture of Lying}

Foucault's genealogical analysis of truth telling in my view requires a supplementary analysis of the practices of lying. After all, the concepts of true and false, truth and falsity, are strictly binary concepts that take their purchase from the contrast of each other, especially in the development of two-value logics or truth table calculus. As Max Urchs (2006) points out while lying is a ubiquitous element of communication, it is almost completely ignored by traditional logic. There is a deep-seated tendency dating from early Christian sources that lying is a defective function of language and that its structure deforms communication to the harm of society generally, even although this normative view is not accompanied by a formal or logical analysis. Urchs (2006: 69) suggests that even with making the assumptions that

In many types of communication, lying is an important element [and]

Deceptive speech acts have some characteristic internal structure. Moreover, in order to be efficient they must respect certain requirements of rationality.

A formal analysis of lying is very difficult. 
He concludes:

To sum up the ... hindrances for an adequate formal analysis of lies we put together the main points.

- lies produce inconsistencies;

- whether an utterance is a lie or not heavily depends on context;

- according to background knowledge there may occur a flic-flac-

effect;

- causal and intentional aspects are indispensable in an analysis of lies.

To be sure, all these topics are handled by modern logic. And yet, to merge them into one formal framework, which remains practically feasible seems hard enough. So it is not surprising that a satisfactory logic of lying is still to come (p. 88).

Urchs (2006) demonstrates the difficulty of proposing a formal account of lying. In the informal sense (in ordinary language as opposed to logical notation), James Mahon (2008) provides the standard definition of lying following Bernard Williams' formulation:

"I take a lie to be an assertion, the content of which the speaker believes to be false, which is made with the intention to deceive the hearer with respect to that content" (Williams 2002, 96); or, more formally:

To lie $=_{\text {df }}$ to make an assertion that is believed to be false to some audience with the intention to deceive the audience about the content of that assertion.

Mahon modifies the definition as:

To lie $=_{\mathrm{df}}$ to make a believed-false statement to another person with the intention that that other person believe that statement to be true.

He unpacks four necessary conditions:

First, lying requires that a person make a statement (statement condition). Second, lying requires that the person believe the statement to be false, that is, lying requires that the statement be untruthful (untruthfulness condition). Third, lying requires that the untruthful statement be made to another person (addressee condition). Fourth, lying requires that the person intend that that other person believe the untruthful statement to be true (intention to deceive addressee condition). 
This logical analysis is useful but lying is also a complex cultural practice that varies across history and cultures and is open to a genealogical analysis. Some idea of its complexity can be gauged both from the difficulty of treating it in a formal system and also it terms of the overlapping network of concepts involving a range of different practices from the white-lie, (Plato's) noble lie, fibbing, the bare-faced lie, to bullshit, bluffing, deceit, deception, and pathological lying. ${ }^{10}$ This list does not mention associated forms of dissimulation, dissembling, propaganda, newspeak, deliberate bias and so on. These associated practices demonstrate how pervasive lying is. If it was to take in these and other forms of behavior, then it would help explain how pervasive lying is in public and personal life. To recognize associated these forms and practice point to the demand for an "anthropology of lying" although I have found no such study or literature. (Ethnography itself seems dependent on "true" narratives of informants and is famously open to distortions as Margaret Mead's experience in recording Pacific stories demonstrates). ${ }^{11}$

I am encouraged to think of lying as a set of cultural practices partly through the influence of Foucault's genealogy. Wittgenstein's (1953) language-game analysis is also very helpful in understanding lying as yet another language game. Wittgenstein writes: "Lying is another language game that needs to be learned like any other one" (para. 241). Lying is not a misuse of language, it is just another language game. Simulation would seem to be one of the basic features of language games of emotions. Buzar et al (2010) take up this point to apply speech act theory to lying:

"to lie" is a speech act like any other and it should be performed properly (satisfied, happy, etc. similar as "to pretend", Austin, 1961:201-20), and "lying is a language-game that needs to be learned like any other one" (it should be learned and practiced properly, Wittgenstein, $2001 \S: 249)$. "Being truthful" and "being lying" or to tell the truth and to tell a lie are practically irrelevant for understanding lying. What seems to be much more interesting are cases where these two are hard to differentiate because there are lies which do not include previous intent to deceive and there are truths which are in fact half-truths, incomplete truths, or avoidances of the truth (p. 34).

Buzar and his colleagues explore the many intermediate cases between lying and truth-telling to conclude,

we lie much more than we in fact believe we do (this rationalisation is part of good practice of various professions like 
business, legal, political, medical etc. as well as our daily life in which habitual lying, is part of upbringing, customs and culture) (p. 38).

It is a substantial argument that brings us back to lying and its ubiquity in public life and also to Hannah Arendt's insightful essay "Lying in Politics" with which this paper began.

Arendt's article consists in a series of reflections on the Pentagon Papers and she bases her assessment on the history of the lie in political culture. In "Truth and Politics" (1967) and "Lying in Politics" (1971) Arendt reflects the fundamental relationship between lying and politics. She explains the nature of political action in the context of lying with surprising consequences that run against modern intuitions and threatens to change our understanding of the history of politics. In "Lying in Politics" Arendt provides an account of political imagination that draws interconnections between "the ability to lie, the deliberate denial of factual truth, and the capacity to change facts, the ability to act." She writes:

when we talk about lying, and especially about lying among acting men, let us remember that the lie did not creep into politics by some accident of human sinfulness; moral outrage, for this reason alone, is not likely to make it disappear. The deliberate falsehood deals with contingent facts, that is with matters which carry no inherent truth within themselves, no necessity to be as they are; factual truths are never compellingly true. The historian knows how vulnerable is the whole texture of facts in which we spend our daily lives; it is always in danger of being perforated by single lies or torn to shreds by the organized lying of groups, nations, or classes, or denied and distorted, often carefully covered up by reams of falsehoods or simply allowed to fall into oblivion. Facts need testimony to be remembered and trustworthy witnesses to be established in order to find a secure dwelling place in the domain of human affairs. From this, it follows that no factual statement can ever be beyond doubt — as secure and shielded against attack as, for instance, the statement that two and two make four. http://www.nybooks.com/articles/archives/1971/nov/18/lying-inpolitics-reflections-on-the-pentagon-pape/

She continues in a Nietzschean vein:

It is this fragility that makes deception so easy up to a point, and so tempting. It never comes into a conflict with reason, because things could indeed have been as the liar maintains they were; lies are often much more plausible, more appealing to reason, than 
reality, since the liar has the great advantage of knowing beforehand what the audience wishes or expects to hear. He has prepared his story for public consumption with a careful eye to making it credible, whereas reality has the disconcerting habit of confronting us with the unexpected for which we were not prepared.

http://www.nybooks.com/articles/archives/1971/nov/18/lying-inpolitics-reflections-on-the-pentagon-pape/

The pervasive role of lying in modern politics requires an historical analysis. Cathy Caruth (2010: 79) explains that Arendt in her earlier work The Human Condition had elaborated the concept of political action that arose in the Greek polis "when words and deeds replaced the mute force of violence and created a public sphere in which men appeared before each other and created the world anew in unpredictable and unexpected ways." Caruth (2010: 80) points out "the public realm has become a realm of deception" and in a world where there is such a conflict between factual truth and politics it is a short step to the denial of history and to the systematic political lying that invests itself in the public realm and creeps into the history books and into the culture more generally.

The real danger, Caruth (2010) maintains, is when the lie loses its traditional role within politics as an alternative means for determining true political action to become an all consuming activity that replaces action and history altogether to deny history and constructing Arendt's words an "entirely fictional world", a possibility hugely enhanced an a world based more and more on PR and "image making" (p. 82). How much more forbidding is Arendt's analysis when it is viewed at the end of the first couple of decades of the twenty-first century when the Internet has become the first truly global medium, the image has become supreme and finance culture has penetrated and percolated to heart of government.

Aidan Markland (2012) examining lying and deception in political culture demonstrates that that there has been significant historical differences in the moral assessment of lying in political culture in the West and adopting a Nietzschean and Foucauldian perspective he argues that lying can serve to shore up and maintain culture:

With the rise of political realism and secular-positivism, the focus of politics shifted from maintaining the moral and psychological well-being of citizens (and the values they live by), to the maintenance of political power and stability for as long a duration as possible (which was central in the works of Machiavelli and Hobbes). Lying, in turn, was then justified as a useful political tool for sustaining political power. By examining the re- 
conceptualization of lying (for the Greeks it could be morally necessary and politically expedient, for the Christians it was morally prohibited) for purposes of merely maintaining power, I attempt to elucidate a crucial way in which lying serves life. Specifically, lying can be used to create the stability of society and the political state that is necessary for maintaining culture and values more generally (p. 14).

There are as far as I can see two saving graces and checks: first, as Markland remarks we should be concerned if lying becomes the province of a oneparty state and, second, drawing on Arendt, the individual lie or even the tissue of lies is only tolerable in the name of true political action and if it ever becomes the singular philosophical principle then we are lost.

\section{NOTES}

1. See the Australian Royal Commission into Institutional Child Abuse at http://www.childabuseroyalcommission.gov.au/. The Interim Report was released on 30 June 2014. I am reminded of the comments of Michael Ignatieff (2001) made in The Guardian: "Since its report came out in 1998, the South African Truth and Reconciliation Commission has become a model for other societies seeking to rebuild their ethical order and find healing and justice after periods of war or tyranny." And we might add "systematic institutional child abuse". He continues: "There are many ways to do this: the de-Nazification of West Germany after 1945 followed by the de-Stasification of East Germany after 1989, the Chilean, Salvadorean and Argentine truth commissions, the international tribunals in The Hague and Arusha, the indictment of Pinochet. In all these processes, the essential problem is how to balance peace and justice, forgetting and forgiving, healing and punishment, truth and reconciliation." And now to the central point he makes relevant to my inquiry: "you cannot create a culture of freedom unless you eliminate a specific range of impermissible lies. I put it this way - a range of impermissible lies - because all societies, and all human beings lie to them selves all the time. Citizens of liberal democracies are fooling themselves if they think we live in truth. None of us can support very much truth for very long. But there are a few lies that do such harm that they can poison a society just as there are a few lies in private life that can destroy a life." See http://www.theguardian.com/theguardian/2001/oct/13/weekend7.weekend3

2. See the inspired review essay "Mendacious Flowers" by Martin Jay (1999) reviewing George Stephanopoulos' All too Human: A Political Education and Christopher Hitchens' No One Left to Lie to: The Triangulations of William Jefferson Clinton.

3. See http://www.law.ua.edu/programs/symposiums/law-and-lies/. The rest of the quotation insofar as it concerns the law runs: "And what is true in our public life is also true in our legal life. While the law recognizes deceit as a cause of action in torts, as the late Arthur Leff famously noted, the law tolerates a lot of deception in 
market transactions. In addition, while law condemns lying under oath, it condones deceptive silence. While law condemns entrapment, it condones deception and decoys as acceptable tools in the enforcement of the criminal law. While the law values truth it defends the right to lie as an aspect of freedom of speech. This conference will investigate the way law responds to lying and deception. When and where are they tolerated? When and where are they condemned? What can we learn about law by examining its attitude toward lies?"

4. Augustine starts his inquiry with the question of the innocent or charitable lie and whether it is right in any circumstances to tell a lie, see http://www.newadvent.org/fathers/1312.htm. Translated by $\mathrm{H}$. Browne. From Nicene and Post-Nicene Fathers, First Series, Vol. 3. Edited by Philip Schaff. (Buffalo, NY: Christian Literature Publishing Co., 1887.) Revised and edited for New Advent by Kevin Knight.<http://www.newadvent.org/fathers/1312.htm>.

5. I am referring to the version of Chapter 3 http://www.rci.rutgers.edu/ stich/104_Master_File/104_Readings/Rachels/Subjectiv ism\%20in\%20Ethics.pdf. The 2011 seventh edition is prepared with Stuart Rachels.

6. See Nietzsche's famous and, apparently, only footnote in the entire corpus of his work, which appears after the first essay of the Genealogy of Morals.

7. This exceprt is from Walter Kaufmann's translation translation, appearing in The Portable Nietzsche, (1976 edition), pp. 46-47, at http://en.wikipedia.org/wiki/On_Truth_and_Lies_in_a_Nonmoral_Sense.

8. These lectures were edited by Joseph Pearson in 1985, compiled from taperecordings made in English by Foucault. As Pearson notes "Since Foucault did not write, correct, or edit any part of the text ..., it lacks his imprimatur and does not represent his own lecture notes". Pearson's version was reedited in 1999 for the web site www.repb.net (accessed 25 July, 2001) which serves as the text to which I refer.

9. I use the male pronoun here on purpose as the parrhesiastes must know his own genealogy and status and is usually a male citizen (see Foucault, 1999: 5).

10. See http://en.wikipedia.org/wiki/Lie that mentions thirty "types" of lying though it is doubful if these are discreet types.

11. It is reported that Americans and Europeans share stereotypical beliefs about the way liars act: characteristically they avert their gaze, turn away, and pause while giving implasuible accounts. Yet these beliefs are "probably false", see Global Deception Research Team (2006). On Mead's alleged hoaxing see Freeman (1999).

\section{REFERENCES}

Baier, K. (1958) The Moral Point of View, Ithaca, Cornell University Press

Bailey, F. G. (1991) The Prevalence of Deceit. Ithaca: Cornell University Press. Bok, S. (1999) Lying: Moral Choice in Public and Private Life, New York: Vintage Books. 
Buzar, S., Jalšenjak, B., Krka, K., Lukin, J., Mladi, D. and Spaji, I. (2010) Habitual Lying, Philosophical Papers and Reviews Vol. 2 (3), pp. 34-39, October, at http://www.academicjournals.org/PPR

Caruth, C. (2010) Lying and History. Thinking in Dark Times: Hannah Arendt On Ethics and Politics, Roger Berkowitz, Jeffrey Katz, and Thomas Keenan (eds.), New York, Fordham University Press, pp. 79-92.

Foucault, M. (1972) The Archaeology of Knowledge, Pantheon Books, New York. Translation from the French. L'Archeologie du Savoir, Gallimard, Paris, 1969.

Foucault, M. (1979) Discipline and Punish: The Birth of the Prison, Vintage/Random House, New York .

Foucault, M. (1980) The History of Sexuality (Vol. 1, 2 and 3), Vintage/Random House, New York.

Freeman, D. (1999) The Fateful Hoaxing of Margaret Mead: A Historical Analysis of Her Samoan Research, Boulder, CO: Westview Press.

Glenn, Paul F. (2004) The Politics of Truth: Power in Nietzsche's Epistemology, Political Research Quarterly, 57 (4): 575-583.

Mahon, James Edwin, The Definition of Lying and Deception, The Stanford Encyclopedia of Philosophy (Fall 2008 Edition), Edward N. Zalta (ed.), URL = <http://plato.stanford.edu/archives/fall2008/entries/lying-definition/>.

Markland, A. (2012) The Genealogy of Lying and Deception in Political Theory. A thesis submitted to the faculty of Wesleyan University in partial fulfillment of the requirements for the Degree of Bachelor of Arts with Departmental Honors in

Government, at http://wesscholar.wesleyan.edu/cgi/viewcontent.cgi?article=1784\&context=etd_ hon_theses

Nietzsche, F. (1967) On The Genealogy of Morals and Ecce Homo, translated and edited by Walter Kaufmann, translation of On the Genealogy in collaboration with R. J. Hollingdale, New York, Vintage.

Nietzsche, F. (1976) On Truth and Lies in an Extra-Moral Sense, in The Portable Nietzsche, translated by Walter Kaufmann, New York, Penguin (first published by the Viking Press, 1954).

Nyberg, D. (1993) The Varnished Truth. Truth Telling and Deceiving in Ordinary Life, Chicago, University of Chicago Press.

Peters, M.A. (2003) Truth-Telling as an Educational Practice of the Self: Foucault, Parrhesia and the Ethics of Subjectivity, Oxford Review of Education, Vol 29, No. 2: 207-223

Rachels, James and Rachels, Stuart (2011) The Elements of Moral Philosophy, New York, McGraw-Hill.

Simpson, D. (2007) Truth, Truthfulness and Philosophy in Plato And Nietzsche, British Journal for the History of Philosophy, 15 (2): 339 - 360.

Urchs, M. (2006) Just Lying, Logic and Logical Philosophy Volume 15: 67-89

Williams, B. (2002) Truth and Truthfulness: An Essay in Genealogy. Princeton: Princeton University Press. 
